Volume 1

Number 1

Fall 2016

\section{The Boller Review:}

A TCU Undergraduate Journal of Research and Creativity

\title{
Dance, The Divine, and The Devious Other: Orientalism and the Presentation of Race and Gender in the Work of Ruth St. Denis by Krista Kee
}

Ruth St. Denis is considered to be one of the pioneers of American modern dance. She was a performer and choreographer often mentioned alongside the historical giants of modern dance like Isadora Duncan and St. Denis's own protégé, Martha Graham. Ruth St. Denis's Eastern-inspired and ornate dance spectacles earned her significant notoriety and enthralled audiences. St. Denis certainly contributed to the evolution of the American modern dance tradition; however, her success also highlights the presence of Orientalist thought in Western culture. St. Denis focused much of her work on what she referred to as Oriental Dancing. Orientalism refers to the idea that the East is spiritual, sensual, and intriguing. Orientalism overlooks the wide variety of cultures and nations in the Eastern Hemisphere and conveniently names them all as exotic other, thus degrading and oversimplifying them. An analysis of two of St. Denis's most prominent works, Incense and Radha, reveals how Orientalism insidiously affects the perception of both race and gender in dance spectacle while reinforcing imperialist attitudes of Western superiority.

Orientalism as a mode of thought was prominent in Western cultures spanning 
from the eighteenth to twentieth centuries, and its echoes regularly emerge today in popular culture and entertainment. In Orientalist thought, cultures of the Eastern hemisphere are considered to be mysterious, exotic, and inherently lesser than those of the West. Rather than understanding the Eastern cultures for their complexities and uniqueness, they were all viewed as the exotic other and often reduced to mere caricatures. Orientalist thought permeated literature, medicine, and the arts. Orientalism is considered to be of the same lineage as imperialist and post-colonial attitudes, clearly reflecting the notion of a superior Western world. In "Dancing the Orient For England" Amy Koritz writes:

The discourse of Orientalism was inextricable from the policies and ideology of English imperialism ... the institutional and discursive practices of Orientalism, practices that established the conceptual polarization of East and West, claimed authority for Western definitions of the Orient and legitimized the domination of Eastern peoples, were an enabling condition of imperialism, not its post-hoc rationalization (64).

We see that Orientalism did not simply emerge as a product of Western nations' imperialistic ventures; rather it was Orientalist thinking that shaped and defined Eastern people as lesser than, uncivilized, and subsequently conquerable. The nature of Orientalism shifts fluidly between a Western domination of and fascination with the Orient.

In his work entitled "Orientalism," Edward Said refers to and examines Orientalism as a field of learned study, citing the presence of programs for "Oriental studies" at major and prestigious universities like Princeton and Oxford. Published in 1975, Said refers to the field of Orientalism as having "considerable geographic 
ambition." He writes that the very name "Orientalism" is rather revealing, as "no one is likely to imagine a field symmetrical to it called Occidentalism" (163). Although Said's writing has been heavily criticized in more contemporary analysis for its lack of attention to the actual colonized subject and an "overreliance on binary opposition," it provides insight into the pervasiveness of Orientalist sentiments (Koritz 64). Even a writer examining the faults of the so-called field of Orientalism overlooks the opportunity to bring attention to the actual people and cultures of the Orient and relies on the paradigm of a divided West and East. While discussing the difficulties of Orientalist study, Said writes:

Since Orientalists have traditionally occupied themselves with things Oriental (a specialist in Islamic law, no less than experts in Chinese dialects and Indian religions, is to be considered an Orientalist by people who call themselves Orientalists), we must learn to accept enormous, indiscriminate size plus an almost infinite capacity for subdivision ... one of the chief things about its confusing amalgam of imperial vagueness and precise detail” (163) While the field of Orientalism may have paid closer attention to details regarding various cultures considered part of the Orient, the arts and entertainment often did not. The imperial ambiguity of Orientalism is present in Hollywood films, artistic depictions, advertisements, and dance works of the early twentieth century.

In light of the influence of Orientalism on twentieth-century thinking and art, it is rather ironic to note that the evolution of modern dance, which is often referred to as a uniquely American art form, featured a great deal of cultural appropriation and subsequent misrepresentation. In an analysis of Ruth St. Denis's performance of Radha (1906), author and dance historian J ane Desmond points out indicators of Orientalism 
present in the work when she writes that Radha presents "a hyberbolization of categories of otherness, mapping markers of race, orientalism, and sexuality onto the white middle-class female body" (30). Female sexuality plays a curious role in Orientalist thought, as female sexuality, like the Orient, is often portrayed as something both fascinatingly mysterious and something to be dominated. Even Freud referred to female sexuality as a "dark continent," implicitly relating female sexuality to colonialism in Africa and revealing the permeation of Orientalist notions in the fields of science and psychology (31).

St Denis's Radha, like many of her works, highlights the way in which Orientalism presents both the Other and female sexuality. St. Denis performs as the Hindu goddess Radha with a bare midriff and flower-adorned hair (31). Since she had never actually studied classical Indian dance forms, she drew on images of India she had viewed in books, and "punctuated her simple phrases with poses that recalled oriental icons" (32). St. Denis's lack of training in Indian dance forms causes the dance to be an appropriation of culture, rather than a representation of it. In many of her works, Ruth St. Denis embodies the figure of what she might term an Eastern goddess, both sensual and sagacious. Radha is no exception. Desmond writes that Radha "projects a vision of the East as a site of imaginary pilgrimage both for sensual indulgence and physical awakening" (40). The tendency of Eastern cultures to be hyper-sexualized in their presentation by Western artists is a hallmark of Orientalist thought, as the East is often seen as the antithesis to the West. Therefore if the West is intellectual, industrial, and powerful, the East is seen as sexual, spiritual, and primitive. We see that Radha embodies these ideas as a Western woman dances the role of a spiritual being who is also undeniably sensual. Radha was well received by audiences and critics alike, as Ruth 
St. Denis's spectacle satisfied turn of the century America's craving for exotica (37).

An analysis of Ruth St. Denis's performance of Incense reveals further influence of Orientalism on her work. Philp Baribault filmed a short recording of the dance in 1953. Incense is a solo performance and Ruth St. Denis is clothed in a dress that appears to resemble a traditional Indian sari. Incense seems to be inspired by Hindu rituals, as the performer at one point in the dance picks up a plate of incense and gently sprinkles it across the stage. St. Denis primarily moves her arms and articulates her fingers. At one point in the work, she walks with one arm bent in front of her body and one arm bent behind. This particular position looks as if she is incorporating what is often inaccurately recognized as an Egyptian walk. The movement content is important because there appears to be a significant amount of cultural appropriation and misrepresentation. In terms of symbols presented, it appears that St. Denis is appropriating movements from Indian cultural relics such as the use of incense in ritual and positions reminiscent of Bharata Natyam, the ancient Indian temple dance.

Contextually, this performance of Incense took place in 1953, much later than Ruth St. Denis's performance of Radha. This particular decade is an especially noteworthy one in American history. The Cold War between the Soviet Union and the United States of America had just begun and the United States military was involved in the Korean Conflict. We start to see traces of the Civil Rights Movement appear during the fifties, which would set the stage for significant social upheaval and change in the 1960s. However, it does not appear that this dance performance was necessarily affected by the political climate. Although her performance of Radha was much later in St. Denis's career and occurred during a historically pivotal time, there appears to be minimal evolution in both concept and content between the two performances. In both 
performances, spaced nearly fifty years apart, Ruth St. Denis embodies an Indian goddess and she utilizes the exoticness of the character to create a potent sense of sensuality. While the rather tumultuous political environment influenced the work of many of her contemporaries, it appears that St. Denis's work was not affected.

In “Ruth St. Denis (1879-1968) America’s Divine Dancer,” Thomas Hecht writes that St. Denis "turned her back on the popular-culture musical theater of the time in favor of more elite entertainment" (1). He suggests that it was St. Denis's focus on the spiritual and divine that distinguished her from the performances of what he refers to as "typical showgirls." St. Denis's fascination with the spiritual world may have been the distinguishing factor between her work and the bawdier popular entertainment, but it may also have been what kept her work separated from political and social influences. Hecht writes, "the eclectic mixture of eroticism and sensuality ... was rooted in her deep passion for spiritual practices" (2). He cites her sudden exposure to a variety of literature in her teen years, particularly Buddhist religious texts, as the impetus for her spiritual practice investigation and her subsequent use of spiritual themes in dance performance (1). Hecht routinely refers to the sensuality and exoticness of St. Denis's work and attributes this to the spiritual component of her choreographic process. However, I argue that it is the Orientalist presentation of St. Denis as a woman of color that contributes to her performances' sensual exoticism.

Historically, women of color have been seen as markers of sexual deviance. This notion is a significant component of Orientalist thought, and its roots are easily uncovered in nineteenth-century European medicinal studies and artwork. In “Black Bodies, White Bodies: Toward an Iconography of Female Sexuality in Late Nineteenth Century Art, Medicine, and Literature," author Sander L. Gilman explores how the 
sexuality of the black female was presented and articulated in the arts and medicine. To justify the presentation of the black female as a symbol of sexual deviance in artistic depictions, the black female was presented as such in medicinal research. Sanders writes:

The black female thus comes to serve as an icon for black sexuality in general . . . Such a scale was employed to indicate the innate difference between the races: in this view of mankind the black occupied the antithetical position to the white on the scale of humanity ... The antithesis of European sexual mores and beauty is embodied in the black. (212)

Medicinal research labeled the black female as more primitive physically, particularly in regard to her primary and secondary sexual characteristics. Researchers claimed black female organs were more sexually developed and cited the black female's "voluptuousness" and "horribly flattened noses" as markers of their sexual deviance and inferiority (213). In artwork, the image of a black woman, usually a servant, would be presented alongside the image of a European woman when the artist wished to suggest that the white woman was promiscuous or "covertly" sexual (211). Black women, and subsequently all women of color, therefore can serve as overt symbols for sexual deviance or flagrant sensuality.

By choosing to portray herself as a Hindu goddess in both Radha and Incense, Ruth St. Denis is further sexualized in the eyes of the audience (Desmond 43). Hindus were considered to be black at this time in North America; therefore, we see how St. Denis's work perpetuates the tradition of using the black female image to represent excessive, or even deviant, eroticism (46). By slipping into the role of a woman of color while on stage, St. Denis was able to present sexually themed performances without 
appearing indecent. In many of her earlier works, St. Denis even appeared in dark body paint, separating her from the chastity of Whiteness and tying her to the excessive sexuality of "darkness"(45). Of course, as a Caucasian woman, once St. Denis left the stage she could leave the hyper-sexualized caricature behind. The cultural implications of this are rather significant.

Cultural appropriation works in tandem with Orientalism in Ruth St. Denis's work. She is able to step into the character of an overtly sexual Eastern woman while performing without incurring the consequences of presenting herself, as a white woman, in a sexual manner. By clothing herself in what was considered Oriental attire and performing movements that were attributed to Eastern cultural dances, St. Denis reinforced sexually charged attitudes regarding women of color while safeguarding herself from appearing indecent. The sensual nature of Ruth St. Denis's performances is a product of her appropriation and subsequent misrepresentation of Eastern culture.

Ruth St. Denis had a strikingly similar contemporary in Maud Allan. Widely considered as artistically superior to Ruth St. Denis throughout England, Maud Allan's dance spectacles were also heavily influenced by Orientalism. She regularly embodied the role of an Eastern goddess in her performances and enjoyed an "unprecedented run" of over 250 performances at the Palace Theatre of London (Koritz 64). In "Dancing the Orient for England: Maud Allan's The Vision of Salome," Amy Koritz examines how Orientalism created a gendered rhetoric about both the nature of women and Eastern people groups in Maud Allan's work. She writes:

The stereotype of the Oriental woman enacted by Allan embodied anxieties about women and Orientals while also affirming the mastery of both by a Western and male defined truth ... Allan made the East transparent to the West by 
representing its essence; but she was not an Eastern native, and therefore could not disrupt its Otherness ... she presented a threatening female sexuality in a way that confirmed its Otherness by identifying it only with Oriental women (68). Koritz could have very easily been writing about one of St. Denis's performances. Like St. Denis, the presentation of Allan as a hyper-sexualized Eastern goddess reinforced Orientalist attitudes regarding the perceived sexual deviance of non-white women. This image of the sexually deviant or threatening Oriental woman serves as a representation of the Eastern world as a whole: sensual, erotic, and therefore worthy of domination by the Western male. By performing in the caricature of an Eastern goddess, Allan created sensual dance spectacles that were not perceived as indecent because she distanced the character from the respectability of white, Western women and reaffirmed the sexual deviance of non-white women. Maud Allan appropriated and erroneously illustrated Eastern culture in her Vision of Salome and other works in a manner that worked to her benefit, drawing enthusiastic crowds and consistently receiving stellar reviews (69).

St. Denis's performances, like Maud Allan's, drew eager audiences and solidified her as an icon of twentieth-century modern dance. We see that St. Denis benefited significantly from cultural appropriation, as audiences and critics alike were enthralled with her sensual dance spectacles. Ruth St. Denis was not classically trained in classical Indian dance, and therefore could not accurately portray or pay homage to the Hindu culture she often sought to embody (Desmond 31). By presenting herself as a woman of color in performance, St. Denis profited artistically and financially without having to incur the cultural ramifications that actual women of color experience. The line between cultural appropriation and appreciation is often blurred. However, in the case of Ruth St. Denis, it is clear that appropriation worked as a function of Orientalist thought which 
served to advance her status as a cultural icon and distort perceptions of the East and female sexuality.

Ruth St. Denis was a captivating performer, and perhaps a victim of her times in regard to the manner in which Orientalist thought permeated her work. It is rather easy to look back and analyze how the presentation of female sexuality and race worked together so insidiously. St. Denis's work was well received by audiences, and her contributions to the evolution of modern dance are substantial. However, it is clear that the lasting effects of Orientalism are present in St. Denis's work, as in other high arts and even medicine of the early twentieth century. Most notably, however, is how damaging Orientalist thought is to the perception of the cultures in the Eastern hemisphere and to black female sexuality. Ruth St. Denis sits rightfully within the pantheon of modern dance innovators, yet the role of Orientalism in her work must always be examined critically and carefully. 
Works Cited

Desmond, J ane. “Dancing out the Difference: Cultural Imperialism and Ruth St. Denis's ‘Radha' of 1906.” Signs 17.1(1991): 28-49. J STOR. Web. 24 Feb. 2015.

Gilman, Sander L. "Black Bodies, White Bodies: Toward and Iconography of Female Sexuality in Late Nineteenth-Century Art, Medicine, and Literature." Critical Inquiry 12.1(1985): 204-42. J STOR. Web. 24 Feb. 2015.

Hecht, Thom. “Ruth St. Denis (1879-1968) America's Divine Dancer.” Dance Heritage Coalition. 1-3. Web. 3 April 2015.

Incense. Dir. Philip Baribault. Perf. Ruth St. Denis. Dance Heritage Coalition, 1953.

Koritz, Amy. "Dancing the Orient for England: Maud Allan's The Vision of Salome."” TheatreJ ournal 46.1(1994): 63-78. J STOR. Web. 24 Feb. 2015.

Said, Edward W. “ORIENTALISM.” The Georgia Review 31.1 (1977): 162-206. J STOR. Web. 24 Feb. 2015. 